\title{
The effect of exchange rate volatility on foreign direct investment in Ghana
}

\author{
Emmanuel Adu Boahen, Oteng Evans* \\ Valley View University, Techiman, Ghana \\ Email address: \\ 19801@yahoo.co.uk (A. B. Emmanuel), evansoteng@yahoo.com (O. Evans)
}

\section{To cite this article:}

Emmanuel Adu Boahen, Oteng Evans. The Effect of Exchange Rate Volatility on Foreign Direct Investment in Ghana. International Journal of Economic Behavior and Organization. Vol. 2, No. 2, 2014, pp. 20-28. doi: 10.11648/j.ijebo.20140202.12

\begin{abstract}
Increasingly, Foreign Direct Investment is assuming a prominent role in the development and growth strategies of developing and emerging countries. Using a Vector Autoregressive (VAR) model, this study demonstrates theoretically that nominal interest rate volatility can simultaneously drive exchange rate volatility and impact on Foreign Direct Investment. It then provides an empirical illustration of the bias this endogeneity can cause when regressing measures of exchange rate volatility on foreign direct investment. It is a detailed study that looks at the long - run and short - run movement of exchange rate volatility, interest rate volatility and foreign direct investment by the use of the Vector Error Correction Model. The study also establishes that a stable exchange rate and interest rate improve Foreign Direct Investment inflow into the country. The study however explains that, the effect of interest on Foreign Direct Investment is indirect. It demonstrates that interest rate volatility directly affects exchange rate and market attractiveness which then affects Foreign Direct Investment in the long run. The paper therefore concludes that government should implement policies that will stabilize both the exchange rate and the interest. The study therefore suggests that policies that will reduce importation should be implemented whiles exportation policies should be enhanced and also government external borrowing should be reduced.
\end{abstract}

Keywords: Foreign Direct Investment, Volatility, Vector Auto Regression and Co-Integration

\section{Introduction}

"In the face of inadequate resources to finance long term development in Africa and with poverty reduction and other millennium development goals (MDGs) looking increasingly difficult to achieve by 2020 , the issue of attracting foreign direct investment (FDI) has assumed a prominent place in the strategies of economic renewal being advocated by policy makers at the national, regional and international levels (UNCTAD 2004)". The above quotation suggests that an expansion in the operations of Multinationals corporations (MNCs) in host countries can help alleviate poverty in those countries. A large literature explores the relationship between FDI and the growth rate of income in both developing and developed countries with inconclusive results. While some studies find a positive relationship between FDI and income growth (Hansen and Rand 2006) other studies find no such relationship (Carkovic and Levine 2005). Empirical studies on the importance of inward FDI in host countries suggest that the foreign capital inflow augment the supply of funds for investment thus promoting capital formation in the host country. Inward FDI can stimulate local investment by increasing domestic investment through linkages in the production chain when foreign firms buy locally made inputs from local firms. Furthermore, inward FDI can increase its foreign exchange earnings, provide job opportunities and is also a source of both physical and human capital accumulation and finally FDI through taxes generates revenues needed by governments for infrastructure development.

Aside providing the capital needed for development, MNCs can alleviate poverty by creating employment in the country. Investments by MNCs often generate new employment (direct employment is higher in Greenfield Investments) and create jobs indirectly through forward and backward linkages with domestic firms. Although there are no data in Ghana to support this argument, it is obvious that MNCs in the country tend to pay higher wages than jobs created by local investors. Harrison (1996) finds that the wage differences between foreign owned firms and domestic firms in Ghana's neighbouring country Cote 
D'Ivoire range from $10 \%$ to about $90 \%$; this would not be different from Ghana's case. Hence Multinational investment is very critical in the Ghanaian economy in our quest to reduce poverty in the country and reach a middle income by 2020 .

Even though, policy makers believe that FDI is the single largest source of capital inflows for a developing country like Ghana, surprisingly the impact of exchange rate on foreign direct investment rarely enters debates over exchange rate management or monetary policy. One reason for this omission could be the lack of conclusive evidence regarding the impact of exchange rate on investment behavior of multinational firms. Various studies provide evidence that multinational firms are likely to consider the level and volatility of exchange rates before investing in overseas branches, but all these studies have yielded conflicting theoretical prediction and empirical results.

The main objective of this study is therefore to determine whether interest rate volatility affects exchange rate volatility which in turn affects the volume of foreign direct investment inflows into the country. This objective is achieved by testing the following hypothesis

1. A stable exchange rate period will have a positive influence on FDI inflows

2. There is a bi - directional relationship of exchange rate volatility on FDI

Data for this study is retrieved from the IFS CD - ROM and the World Bank CD - ROM. Where the information seeking on data is unavailable, the data is then collected from Ghana Statistical Service (GSS) and Ghana Investment Promotion Council (GIPC).

\section{Literature Review}

\subsection{Theories and Empirical Evidence on FDI}

Literature on FDI actually began with Dunning in the late 70 s when he came out with the principle of ownership advantage, location advantage, and thirdly internalization advantage of firms. This principle popularly known as "OLI paradigm" was a very useful tool for economist (especially development economist) in putting together different features of firms. Dunning said the propensity of a country to be an inward or outward investor intend depended on the relative competitive strength of the domestic firm vis-à-vis multinational enterprises (MNEs) in ownership and location specific and their abilities to internalize cross-border market transactions (Dunning 1992, page 40).

Numerous other studies can be grouped together because they all focused on economic conditions and/or government economic policies as important location factors affecting firms FDI decisions. Some of these studies were thus related to Dunning's third explanatory conditions for FDI, i.e. the locational advantages of particular countries. The economic conditions included the size of the market, as indicated by GNP, GDP or growth rate in most indicators of macroeconomic conditions; they were frequently found to be positively related to FDI (Contractor 1991). This was a marketing-oriented explanation that focused on the revenue generating expectations associated with a firm's marketseeking strategy. Of course, as noted above since many FDI project had cost reduction as their strategic objective, the market size in the host country may be entirely irrelevant. In any case, the market size theory did not explained why FDI is used rather than exporting licensing as a strategic alternative. It did not also explain how foreign firms can compete with local firms. The extent that market size was a factor in explaining FDI flows, in at least two kinds of government policies were important, in the first place, monetary and fiscal policies that stimulated ( or retarded) growth were significant determinant of the sizes and growth rate for market for all goods and services in the economy. In the second place, government budget priorities that directly or indirectly affected demand for goods and services in some sectors of the economy, rather than others, also were important for market size and growth rate. Some of the early theories about FDI treated it as an international transfer of financial capital, and it was consequently assumed to be responsive to cross-national differentials in the rates of return on capital.

Frimpong and Oteng-Abeyie (2006) did a bivariate analysis between FDI inflows and economic growth in Ghana. The main objective of their paper was to test the direction of causality between foreign direct investment inflows ( FDI ratio) and economic growth (GDP growth) for Ghana focusing mainly on the pre and post SAP periods. Their empirical findings based on the Toda-Yamamoto Granger Causality test clearly suggested identical results for the first two set of periods, namely the entire block period of 1970-2002 and the pre SAP period of 1970-1983. In both cases, there was no evidence of either Growth driven FDI or FDI-led growth. Concerning the results for the post SAP period, i.e. 1984-2002 were the economy had enjoyed a relative political stability and economic focus, they found out evidence of FDI-led growth. Thus, FDI caused improvement in GDP growth in Ghana. The study, however, still failed to confirmed Growth -driven FDI suggesting that GDP growth in Ghana had not being attracting FDI inflows.

\subsection{Theories and Empirical Evidence of Effects of Bilateral Exchange Rate (or Volatility of Exchange Rate) on FDI}

Impact of exchange rate on FDI can be explained by two principal effects. The first is the changes in volatility of exchange rates and the second is changes in the bilateral level of the exchange rate between countries. Froot and Stain (1991) presented a view of an imperfect capital market, showing why country's currency appreciation may actually increase foreign investment by a firm. This view was however in contrast to an earlier existing believe that the exchange rate would not alter the decision by a firm to invest in a foreign country. Froot and Stain(1991) analyzed 
how exchange rates through the imperfect capital market affect FDI. The key contribution provided by Froot and Stain (1991) is a parsimonious model based on informational imperfections that generate a link between economywide FDI and aggregate variables, such as the real exchange rate. They conducted a simple statistical test within the period under consideration which suggested that, a 10 percent dollar depreciation was associated with additional FDI inflows of about $\$ 5$ billion. Moreover, they argued that the correlation was not just a recent development, once one accept that there is a link between wealth positions and investment, the relationship between exchange rate and FDI follows immediately. This means foreigners will hold more of their wealth in non-dollar denominated form; a depreciation of the dollar would increase the relative wealth position of foreigners and hence lower their relative cost of capital. This would allow them to bid more aggressively for assets. Klein and Rosengren (1994) confirm Froot and Stein research that exchange rate depreciate increases U.S FDI. However Stevens (1998) found that the studies of Froot and Stein, and Klein and Rosengrens' empirical studies hold due to the way they specify their models.

Blonigen (1997) also studied inward FDI on Japanese economy when exchange rate changes. He however explained different processes whereby changes in exchange rate affect FDI for a host of countries. The objective of his research was to test the assertion that a depreciated of a country's currency may allow increase in sale of such transferable assets to foreign firms operating in global markets versus domestic firms that may not have such access. He used industry-level on Japanese mergers and acquisition FDI into the U.S to test this objective. His studies found a strong support of increased U.S acquisition FDI by Japanese firms in response to real dollar depreciations relative to the YEN as predicted Blonigen found that this exchange rate effect the acquisition FDI where primarily for high technology industries where firms' specific assets were likely of substantial importance. Numerous studies have found consistency in short-run movement in exchange rates and its impact on inward FDI. Grubert and Mutti (1991) Swenson, and Kogut and Chang (1996) all have their empirical evidence supporting the hypothesis of Blonigen (1997), and Froot and Stein (1991).

Some researchers however had an opposing view to Bloginen (1997) and Froot and Stein ideas of exchange rates on FDI inflows. Campa (1993) used the options theory of dixit (1989) to establish why greater exchange rate uncertainty increases the options for firms to wait until investing in a market and thereby depressing the current FDI. Goldberg and Koldsad (1995) tested a similar hypothesis of campa (1993) and the result supported Campa (1993) evidence to be true.

Arbenser (2007) studied the impact of inward FDI on Ghana using general equilibrium analysis. He focused his analysis on the impact of u-surge in FDI inflow and commercial trade policy simulations on the welfare of households and selected macroeconomic indicators in Ghana prior to 1980 . These ware some of his findings, exchange rate depreciated which caused exports to increased. This led to improvement in the trade deficit causing it to decline by some percentage points. He also found out that, if tariff levels are reduced, domestic demand for import would be increased thereby raising domestic import. In currency terms, quantity of domestic currency would shoot up thereby causing the currency to depreciate. There would be a multiplier effect on exports as a result of the depreciated currency, the demand for exports would go up causing a rise in export levels and subsequently a reduction in trade deficit. The paper revealed that a policy that ensures increase in FDI inflow and that which reduces tariff levels were complementary policies that enhance household welfare in Ghana.

From the literature, most of the studies conducted in the advanced world suggested that depreciation of the local currencies led to a more FDI inflows (Froot and Stein 1991). Campa (1993) and others however had different views to Froot and Stein (1991). Giving these mixed findings concerning exchange rate depreciation or stability in attracting FDI inflows, it could be seen from their studies that, their outcomes depended on the methodology used. Most of the studies talks about investors more concerned about the sunk cost they would incur and profit they would make, therefore exchange rate and interest rate stability will reduce the investment risk of these investors and hence they will be happy to invest in such environment. The next two chapters will use data from Ghana to ascertain whether the Ghanaian case supports Froot and Stein (1991) or Campa (1993) which states that no such relationship exists between the two variables under consideration.

\section{Methodology}

\subsection{Background to the Choice of Econometric Model}

Economists frequently formulate an economically wellspecified model as the empirical model and apply statistical methods to estimate its parameters. In contrast, statisticians might formulate a statistically well-specified model for the data and analyze the statistical model to answer the economic questions of interest. Most of the empirical literature noted above attempted to analyse exchange and interest rate volatility effects on FDI using other econometric framework like the structural equation framework, OLS and general equilibrium analysis assuming implicitly or explicitly variables stationarity and exogeneity. The assumption of stationary variables appears to be troublesome in view that, macroeconomic data usually exhibit unit root.

Simultaneity bias or endogeneity problem may also raise special concern in investment, interest rate and exchange rate. In this regard, we may exemplify by pointing out a potential endogeneity on the part of the two variables commonly featured on the right-hand side of investment 
equations; exchange rate and interest rate volatility. Whiles the whole of the multiplier analysis rests on the behavioral relationship where exchange rate and interest rate variability affects FDI. The reverse of FDI affecting exchange rate and interest rate through economic growth provides a battle ground and controversies since there is no strict economic theory for these relationships. Endogeneity and non stationary problems may be overcome by adopting a system of equations such as the vector autoregressive (VAR) system, modeling technique introduced in the seminal work of Sim (1980).

In estimating the model, bilateral exchange rate will be considered and the chosen currency will be the U.S dollar. This is because, it is the commonest foreign currency traded in the various foreign exchange markets in Ghana over the period under consideration. More so, the GIPC 2006 fourth quarterly report classified all investment projects on the Ghanaian economy into various countries, the U.S economy was the fifth largest that invested in the country. However, the first, second and fourth largest countries that invested in were India, china and Lebanon respectively, investors from all these countries have to convert their currencies into U.S dollars before they can invest in the Ghanaian economy. Hence the market rate of the Ghanaian cedi to the U.S dollar is an appropriate

\section{Equation 3.2}

$$
\begin{aligned}
& \mathrm{FDI}_{\mathrm{t}}=\mathrm{A}_{1} \mathrm{D}_{1}+\sum_{\mathrm{i}=1}^{\mathrm{n}} \mathrm{a}_{1 \mathrm{i}} \mathrm{E}_{\mathrm{t}-\mathrm{i}}+\sum_{\mathrm{i}=1}^{\mathrm{n}} \mathrm{b}_{1 \mathrm{i}} \mathrm{R}_{\mathrm{t}-\mathrm{i}}+\sum_{\mathrm{i}=1}^{\mathrm{n}} \mathrm{c}_{1 \mathrm{i}} \mathrm{FDI}_{\mathrm{t}-\mathrm{i}}+\sum_{\mathrm{i}=1}^{\mathrm{n}} \mathrm{d}_{1 \mathrm{i}} \mathrm{M}_{\mathrm{t}-\mathrm{i}}+\mathrm{T}+\varepsilon_{1 \mathrm{t}} \\
& E_{t}=A_{2} D_{2}+\sum_{i=1}^{n} a_{2 i} E_{t-i}+\sum_{i=1}^{n} b_{2 i} R_{t-i}+\sum_{i=1}^{n} c_{2 i} F I_{t-i}+\sum_{i=1}^{n} d_{2 i} M_{t-i}+T+\varepsilon_{2 t} \\
& \mathrm{R}_{\mathrm{t}}=\mathrm{A}_{3} \mathrm{D}_{3}+\sum_{\mathrm{i}=1}^{\mathrm{n}} \mathrm{a}_{3 \mathrm{i}} \mathrm{E}_{\mathrm{t}-\mathrm{i}}+\sum_{\mathrm{i}=1}^{\mathrm{n}} \mathrm{b}_{3 \mathrm{i}} \mathrm{R}_{\mathrm{t}-\mathrm{i}}+\sum_{\mathrm{i}=1}^{\mathrm{n}} \mathrm{c}_{3 \mathrm{i}} \mathrm{FDI}_{\mathrm{t}-\mathrm{i}}+\sum_{\mathrm{i}=1}^{\mathrm{n}} \mathrm{d}_{3 \mathrm{i}} \mathrm{M}_{\mathrm{t}-\mathrm{i}}+\mathrm{T}+\varepsilon_{3 \mathrm{t}} \\
& \mathrm{M}_{\mathrm{t}}=\mathrm{A}_{4} \mathrm{D}_{4}+\sum_{\mathrm{i}=1}^{\mathrm{n}} \mathrm{a}_{4 \mathrm{i}} \mathrm{E}_{\mathrm{t}-\mathrm{i}}+\sum_{\mathrm{i}=1}^{\mathrm{n}} \mathrm{b}_{4 \mathrm{i}} \mathrm{R}_{\mathrm{t}-\mathrm{i}}+\sum_{\mathrm{i}=1}^{\mathrm{n}} \mathrm{c}_{4 \mathrm{i}} \mathrm{FDI}_{\mathrm{t}-\mathrm{i}}+\sum_{\mathrm{i}=1}^{\mathrm{n}} \mathrm{d}_{4 \mathrm{i}} \mathrm{M}_{\mathrm{t}-\mathrm{i}}+\mathrm{T}+\varepsilon_{4 \mathrm{t}}
\end{aligned}
$$

Where $\mathrm{M}$ is market attractiveness, $\mathrm{T}$ is trade openness, $\mathrm{R}$ is interest rate volatility and $\mathrm{E}$ is exchange rate volatility. However, $\mathrm{T}$ is treated as exogenous variable since the decision of a country to employ liberalization lies within the policies of the country and therefore FDI can not affect the country's tax policies on trade. $\varepsilon_{1 \mathrm{t}}, \varepsilon_{2 \mathrm{t}}, \varepsilon_{3 \mathrm{t}}, \varepsilon_{4 \mathrm{t}}$ are

uncorrelated white noise. The determination of the lag length of the model will also depend on efficiency criterion (like the Akaike Information Criterion (AIC) and the Swartz criterion (SBC) of the model which is estimated at different lag length).

The error correction of equation 4.2 is given as;

$$
\left(\begin{array}{c}
\Delta \mathrm{FDI}_{\mathrm{t}} \\
\Delta \mathrm{E}_{\mathrm{t}} \\
\Delta \mathrm{R}_{\mathrm{t}} \\
\Delta \mathrm{M}_{\mathrm{t}}
\end{array}\right)=\psi D_{t}+\Pi\left(\begin{array}{c}
\mathrm{FDI}_{\mathrm{t}} \\
\mathrm{E}_{\mathrm{t}} \\
\mathrm{R}_{\mathrm{t}} \\
\Delta \mathrm{M}_{\mathrm{t}}
\end{array}\right)+\Gamma_{1}\left(\begin{array}{c}
\Delta \mathrm{FDI}_{\mathrm{t}-1} \\
\Delta \mathrm{E}_{\mathrm{t}-1} \\
\Delta \mathrm{R}_{\mathrm{t}-1} \\
\Delta \mathrm{M}_{\mathrm{t}-1}
\end{array}\right)+\cdots+\Gamma_{i}\left(\begin{array}{c}
\Delta \mathrm{FDI}_{\mathrm{t}-\mathrm{i}} \\
\Delta \mathrm{E}_{\mathrm{t}-\mathrm{i}} \\
\Delta \mathrm{R}_{\mathrm{t}-\mathrm{i}} \\
\Delta \mathrm{M}_{\mathrm{t}-\mathrm{i}}
\end{array}\right)+\mathrm{T}+\left(\begin{array}{c}
\mathrm{V}_{1 \mathrm{t}} \\
\mathrm{V}_{2 \mathrm{t}} \\
\mathrm{V}_{3 \mathrm{t}} \\
\mathrm{V}_{4 \mathrm{t}}
\end{array}\right)
$$

\section{Equation 3.3}

Where $\Pi, \Gamma_{1}, \Gamma_{2}, \ldots, \Gamma_{i}$ are matrices and $\Gamma_{1}, \Gamma_{2}, \ldots, \Gamma_{i}$ gives short run dynamics and $\Pi$ long-run co-integration.

Hence, the essence of conducting co-integration analysis is to

(1) Test for the presence of long-run stationary relationship(s) between the variables.

(2) Estimate long-run parameters $\beta$, (co-integration vectors).

(3) Estimate long run coefficients of adjustments $\alpha$, (loading coefficients) and

(4) Employ long-run information to estimate Vector 
Error Correction Models (VECM) which describes short term dynamics. Given the non-stationarity nature of the time series of macroeconomic variables, we will employ unit root test in our analysis. We follow Doornik and Hendry to estimate equation (1) restricting the trend to enter co-integrating space.

Equation (2) is estimated with a constant and a linear trend since exclusion of linear trend in unit root variables in levels is problematic. Another crucial issue in VAR analysis is the determination of the lag length $k$. We adopt a generalto-specific procedure starting with a slightly lengthy lag of which we will then choose the best lag length appropriate for the data.

\section{Discussion of Findings}

\subsection{Unit Root Test Using ADF Estimation Method}

We run a series of test with different lags introduced and also changing of the deterministic component in the ADF equation with E-Views. Both the Akaike information criterion (AIC) and Swartz information criterion (SBC) helps us to select the best lag length for the ADF model. The result of the ADF test is reported in the table 1 below. From the table, $\mathrm{k}$ represents the number of lags that makes the model efficient from the values obtained from the AIC. LFDI and LM respectively show $\log$ of FDI and $\log$ of Market attractiveness. DLFDI, DVOLTE, DVOLTI, DT and DLM respectively show first difference of LFDI, VOLTE, VOLTI, T and LM.

Table 4.1. Unit Root test using ADF procedure

\begin{tabular}{lccll}
\hline Variable & K & ADF & $\begin{array}{l}\text { Deterministic } \\
\text { term }\end{array}$ & $\begin{array}{c}\text { AIC critical } \\
\text { values }\end{array}$ \\
\hline LFDI & 3 & -0.68 & $\begin{array}{l}\text { No trend but } \\
\text { intercept } \\
\text { No trend but }\end{array}$ & $-3.64(-2.95)$ \\
D(LFDI) & 3 & $-3.89 * *$ & $\begin{array}{l}\text { intercept } \\
\text { No intercept and } \\
\text { no trend }\end{array}$ & $-3.64(-295)$ \\
VOLTE & 1 & $-2.99 * *$ & $\begin{array}{l}\text { No trend but } \\
\text { intercept } \\
\text { No trend but } \\
\text { intercept } \\
\text { No trend but }\end{array}$ & $-3.64(-2.95)$ \\
D(T) & 1 & -1.09 & $-3.64(-2.95)$ \\
VOLTI & 1 & $-2.96 * *$ & $\begin{array}{l}\text { intercept } \\
\text { No trend but } \\
\text { intercept } \\
\text { No trend but } \\
\text { intercept } \\
\text { No trend but } \\
\text { intercept }\end{array}$ & $-3.66(-2.96)$ \\
D(VOLTI) & 4 & -2.58 & $-3.67(-2.97)$ \\
LM & 1 & -2.55 & $-4.35 * *$ & $-3.64(-2.95)$ \\
\hline DM & 1 & & &
\end{tabular}

(**) represents $1 \%(5) \%$ significance level respectively

(*) represents $5 \%$ significant level

From table 4.1, it is seen that all the variables except VOLTE are integrated of order one. Both T and VOLTI are significant under five percent significant level whiles the ADF test statistics for VOLTE, LFDI and M shows one percent significance level. The presence of unit root for four of the variables justifies the adoption of VAR modeling technique. Technically, endogenous variables under VAR system are explained by the lagged values of the variables and lagged values of all other variables in the system.

\subsection{Choice Criteria for the Selection of the Order of the VAR Model}

In trying to estimate the VAR model, it is very prudent to consider the best lag length that makes the model more efficient. The Log L, AIC, SBC, LR, FPE and HQ are presented as follows:

Table 4.2. Test statistics and choice criteria for selecting the order of the VAR model

\begin{tabular}{ccccccc}
\hline Lag & Log L & LR & FPE & AIC & SBC & HQ \\
\hline 0 & 5.2841 & NA & 0.0001 & -0.2076 & -0.0589 & -0.1726 \\
1 & 29.9511 & 40.3641 & $3.97 \mathrm{e}-05$ & -1.6319 & $-1.0368^{*}$ & -1.4917 \\
2 & 37.2082 & 9.8960 & $4.93 \mathrm{e}-05$ & -1.4739 & -0.4320 & -1.2281 \\
3 & 45.6765 & 9.2382 & $5.99 \mathrm{e}-05$ & -1.4245 & 0.0627 & -1.0779 \\
4 & 52.5817 & 5.6498 & $9.91 \mathrm{e}-05$ & -1.2347 & 0.6994 & -0.7791 \\
5 & 79.4403 & 14.6501 & $3.72 \mathrm{e}-05^{*}$ & $-2.8582 *$ & -0.4778 & -2.2974 \\
\hline
\end{tabular}

* indicates lag order selected by the criterion

$\mathrm{LR}=$ sequential modified LR test statistic (each test at $5 \%$ level)

$\mathrm{FPE}=$ final prediction

$\mathrm{AIC}=$ Akaike information criterion

$\mathrm{SBC}=$ Schwarz information criterion

$\mathrm{HQ}=$ Hannan-Quinn information criterion

From table 4.2, it is realized that LR test keeps on falling from 40.3642 till it reaches a minimum of 14.6501 at lag 5 and the LR test select lag 1. The magnitude of FPE falls from no lag to one and starts to increase from one lag to lag 4. The FPE then falls again at lag 5; it selects this lower magnitude at lag 5. The AIC also alternates in magnitude and absolute terms as well as selecting higher absolute magnitude lag length of 5. Similarly SBC select lag length of 2 which gives a higher magnitude of 1.0368 in absolute terms. HQ also selects a higher magnitude of 2.2974 in absolute terms at lag 5. Higher AIC, SBC, FPE and HQ information criteria gives indication of how efficient the estimated VAR will be. Hence these selection criteria reported by E-Views show that either lag length one or five makes the VAR model efficient. As earlier said VAR $(1,1)$ is selected to save more degrees of freedom. AR root test which is not reported shows that no root lies outside the unit circle. Hence VAR $(1,1)$ satisfies the stability condition.

\subsection{Co-Integrated Finite Vector Auto-Regressive System and Stationary Long-Run Relationships}

We have five variables LFDI, VOLTE, VOLTI T and LM spanning annual data over the period 1970-2005. Since T is treated as exogenous variable, the system will comprise of four equations whose variables are mostly integrated of order one, i.e. 1(1). The deterministic matrix holds an 
unrestricted constant and exogenous variable which does not enter the co-integrating space of long-run relations. We employ E-Views which is base on Johansen (1988), to determine the co-integration rank ( $r$ ) and estimate the adjustment coefficients $\alpha(\mathrm{s})$ and co-integrating vector(s) $\beta$. Results are reported in Table 3. Co-integration test statistics for the five variables, first-order VAR of LFDI, VOLTE, VOLTI, T and LM indicates that two co-integrating vector exists. The critical values of the trace statistics reported from E-Views for the reduce rank test is given by Osterward-Lenum (1992) but not those tabulated by Johansen and Julius (1990).

Table 4.3. Co-integration ranks of the VAR model.

\begin{tabular}{ccccc}
\hline $\begin{array}{c}\text { Eigen } \\
\text { Value }\end{array}$ & $\begin{array}{c}\text { Likelihood } \\
\text { ratio }\end{array}$ & $\begin{array}{c}\mathbf{0 . 0 5} \\
\text { Critical } \\
\text { value }\end{array}$ & $\begin{array}{c}\mathbf{0 . 0 1} \\
\text { Critical } \\
\text { values }\end{array}$ & $\begin{array}{c}\text { Hypothesized } \\
\text { No CE(s) }\end{array}$ \\
\hline 0.7684 & 90.5450 & 62.99 & 70.05 & None** \\
0.6038 & 49.5869 & 42.44 & 48.45 & at most one** \\
0.4987 & 23.6613 & 25.32 & 30.45 & at most two \\
0.1431 & 4.3247 & 12.25 & 16.26 & at most three \\
\hline
\end{tabular}

Note: exogenous variables are not included in co-integration estimation. $*(* *)$ denotes rejection of the hypothesis at the $0.05(0.01)$ level LR test indicates 2 co-integrating equation(s) at the 0.01 level

The null hypothesis that there is no co-integrating vector in the system $(\mathrm{r}=0)$ is rejected at $5 \%$ significant level and the null of at most one co-integrating $(\mathrm{r} \leq 1)$ vector is also rejected at $5 \%$ significant level as shown in table above. However, the null hypothesis that, there is at most two cointegrating vector $(\mathrm{r} \leq 2)$ is not rejected at $5 \%$ significant level. Subsequently the null that there exists at most three co-integrating vector $(r \leq 3)$ will not be rejected. Hence $\mathrm{H}_{\mathrm{o}}$ : $\mathrm{r} \leq 2$ and $\mathrm{H}_{0} \leq 3$, are not reject since the Likelihood Ratio reports 23.6613 and 4.3247 respectively. These Likelihood Ratios are respectively lower than the $5 \%$ critical values of 25.32 and 12.25. however for $H_{0}: r=0, H_{0}: r \leq 1$, the Likelihood Ratios report a magnitude of 90.5450 and 49.5869 which are respectively greater than the $5 \%$ critical value of 70.05 and 48.45 . Hence the two hypothesis $\mathrm{H}_{\mathrm{o}}: \mathrm{r}=0$ and $(r \leq 1)$, are rejected. This shows two co-integrating vectors as reported in table 3 .

Since there are two co-integrating vectors, the vector error correction model (VECM) is reported in table 5.4 below. The unrestricted normalized co-integrated equation is reported in (panel a in table 5.4). as shown in (table 4 panel a) above, volatility of exchange rate has a negative significant long-run impact on FDI. However, volatility of interest rate has a positive long-run effect on FDI though statistically insignificant at 0.05 level. The negative significance of volatility of exchange rate on FDI shows that, in situations where exchange rate is more stable, FDI increases in the country. On the contrary, volatility of exchange rate reduces FDI inflows; this may be due to increase in investment uncertainty when exchange rate is unstable.
Table 4.4. Long-term and short-term Error Correction Model

Panel a. Normalized co-integrating coefficients: 1 co-integrating equation(s).

\begin{tabular}{cccccc}
\hline LFDI & VOLTE & VOLTI & LM & TREND & C \\
\hline \multirow{2}{*}{1.0000} & 0.9499 & -5.4426 & -6.8856 & 0.0000 & 38.5880 \\
& $(8.1983)$ & $(-10404)$ & $(-3.3240)$ & & 3.2815 \\
\multirow{2}{*}{0.0000} & \multirow{2}{*}{1.0000} & 1.8742 & -0.6399 & 0.0065 & 3.2815 \\
\hline
\end{tabular}

The values in parenthesis are t-values

Panel b. Error Correction Model

\begin{tabular}{lcccc}
\hline & D(LFDI) & D(VOLTE) & D(VOLTI) & D(LM) \\
\hline D[LFDI(-1)] & 0.0624 & 01154 & 0.0032 & 0.0125 \\
D[VOLTE(- & $(0.2605)$ & $(0.5666)$ & $(0.0992)$ & $(0.2490)$ \\
$1)]$ & -0.6931 & -1.0110 & -0.1718 & -7.226 \\
D[VOLT(-1)] & $(-1.1183)$ & $(-5.3118)$ & $(-2.0253)$ & $(-5.5596)$ \\
& -0.5843 & 1.0395 & -0.2864 & 0.9203 \\
D[LM(-1)] & $0.4301)$ & $(2.4915)$ & $(-1.5450)$ & $(-5.5596)$ \\
& $(0.4496)$ & $(2.6991)$ & $(3.0030)$ & $(3.6863)$ \\
C & -0.2444 & 0.1702 & -0.0316 & 0.7595 \\
& $(-0.2529)$ & $(0.5737)$ & $(-0.2329)$ & $(3.7468)$ \\
T & 0.8284 & -0.4075 & 0.0713 & -1.7879 \\
& $(0.3801)$ & $(-0.6081)$ & $(0.2393)$ & $(-3.9116)$ \\
\hline
\end{tabular}

Note: t-test is in parenthesis

Panel C. adjustment coefficients (t-values are in parenthesis)

\begin{tabular}{ccc}
\hline \multicolumn{3}{c}{ Restricted standardized adjustment coefficients $\boldsymbol{\alpha}:$} \\
& $\boldsymbol{\alpha}_{\mathbf{1}}$ & $\boldsymbol{\alpha}_{\mathbf{2}}$ \\
\hline LFDI & $-0.0063(-0.0911)$ & $-0.8167(-0.9267)$ \\
VOLTE & $-0.0101(-0.4765)$ & $-0.8847(-4.5536)$ \\
VOLTI & $-0.0073(-0.7722)$ & $-0.3731(-4.0715)$ \\
LM & $0.0915(6.2906)$ & $-0.2882(-1.6825)$ \\
\hline
\end{tabular}

Volatility of the Cedi against the Dollar is always in the form of depreciation of the domestic currency. Since the Ghanaian economy is highly an imported economy, increase in volatility of exchange rate increases domestic prices of commodities. Hence one can explain that volatility of exchange rate in the country affects prices of inputs of foreign investors and therefore increases production cost of foreign investors. The increase in price of inputs of investors may be in the form of increase in price of labour, raw materials which is one of the main determinants of FDI. Foreign investors therefore prefer to wait until the exchange rate of the economy stabilizes to reduce risk of investment.

The coefficients of VOLTE and VOLTI can be interpreted as long-run partial elasticities of FDI with respect to volatility of exchange rate and volatility of interest rate. The positive significant relationship between market attractiveness and FDI of the regression is also economically meaningful since most of the recent FDI inflows are in telecommunication, financial institutions and manufacturing products which are basically produce for the local market. Hence, the paper suggests that current FDI 
inflows depend on per capita income and the rate of economic growth. The second co-integration equation in table 4.4 panel a suggest that the long run relationship between volatility of exchange rate and both volatility of interest rate and market attractiveness are insignificant. This insignificance may be economically meaningful since there may be other important determinants of trade that may spike exchange rate volatility than interest rate volatility and market attractiveness.

Specifically, the long-run relationship and the Error Correction Term (ECT) of the model can be express as:

\section{LFDI=-38.588-0.9499VOLTE+5.4426VOLTI+6.8856LM}

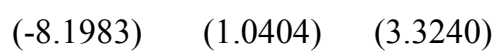

\section{VOLTE $=-3.2815-1.8742 \mathrm{VOLTI}+0.6399 \mathrm{M}-0.0065$ trend}

\section{$(-1.8335) \quad(1.9159)(-1.0001)$}

the $\mathrm{t}$-statistics for the respective variables in the equations above are represented in parenthesis. The first equation shows that, the coefficient of volatility of interest rate is not statistically significant. The regression therefore indicate that interest rate volatility have no effect on FDI inflows to the country. This may be due to the insufficient funds in the domestic capital market and therefore foreign investors prefer to look for funds in the world capital market than the domestic capital market.

(Panel b of table 4.4) also show short-term dynamics or the $\mathrm{I}(0)$ VAR(1) system which comprises of changes foreign direct investment, volatility of exchange rate, volatility of interest rate, market attractiveness and trade openness. The system is estimated by unrestricted ordinary least-squares. The effect of all the four variables on FDI in the short-term is insignificant under 0.05 level. In the same vein, the insignificance of volatility of interest rate in the short run may again be attributed to the weak capital market in the country. Since foreign investors find it difficult to get funds from the local capital market, they rather look at the world market for loans than looking into the Ghanaian Economy. For the case of exchange rate, a short-term stable exchange rate period does not tell much about the country's exchange rate trend this is because exchange rate has over the years being erratic. Foreign investors therefore may wait for some period of time to know the real trend of the exchange rate in the country. This may be the reason for the short-term insignificance. Market attractiveness and trade openness is always possible to detect in the long run since it takes long period for a country to move form a restricted economy to a more liberal economy. Hence foreign investors will take time to ascertain whether the improvement in trade for a particular period is not just a one time change but rather a perpetual change. Similarly, improvement in per capita income and economic growth takes quite a period of time to be realized. The effect of volatility of interest rate on volatility of exchange rate is however positive and significant in the short-run. The paper therefore suggests that interest rate uncertainty in Ghanaian economy can lead to exchange rate uncertainty in the short-run. The positive relationship between the two variables shows that increase in interest rate will cause increase in depreciation in the country's currency. On the contrary, the effect of volatility of interest rate on exchange rate statistically not different from zero, signifying that in the longer-term economic agents will be more informed and will therefore not act on short-term changes of interest rate.

(Panel c of table 4.4) carries a report on the adjustment of loading factors which shows that volatility of exchange rate adjusts to the long-run equilibrium path quicker than that of volatility of interest rate. This indicated by the larger magnitude of the loading parameter $\alpha$ reported for volatility of exchange rate as against volatility of interest rate. (Adjustment parameter of VOLTE is 0.0101 or 0.8847 and that of VOLTI is 0.0073 or 0.37 ).

\section{Conclusion}

Since almost all the variables in this paper are nonstationary and present a unit root, the Johansen's cointegration results provide a unique co-integrating vector. In other words a long-run stable relationship between the variables under consideration exists. The results show that volatility of exchange rate and FDI move together in the long-run, but the relationship between volatility of interest rate and FDI is not empirically significant in the long-run.

Empirical discussion in this paper reveals that while volatility of exchange rate exerts negative long-run effect on foreign direct investment, volatility of interest rate exerts positive effect on foreign direct investment. In view of the depreciating nature of the Ghanaian currency over the years, we can say that foreign investors prefer investing in the more stable period than in a depreciation period. This is because exchange rate volatility increases the investment risk of foreign investors, since foreign investors have to incur certain amount of cost that cannot be recovered upon exit. This sunk cost of the foreign investor may be in the form of training of management, hiring of offices etc. volatility of exchange rate makes such cost uncertain and increase the risk of investment in the country. Moreso, since current FDI inflows into the Ghanaian economy are in the form of establishing or augmenting Deposit Money Banks, Telecommunications and Manufacturing products like (soaps, drinks, oil etc.) which are largely consumed in the country than exporting it, then the profit foreign investors accrue for operating in the economy will be in Cedis. Hence, in a depreciating environment, profits of these investors are decreased when they tried to change it into dollars before repatriating it to their home country. This therefore suggests that foreign investors being concerned about risk of investment and profit after investment will actually prefer investing in a more stable cedi-dollar exchange rate period. As a result, the study suggests that the increase in FDI in recent years can be partially attributed to the more stable exchange rate of cedi- 
dollar that the country has enjoyed in recent years. The insignificance of the long-run effect of interest rate on FDI in the country may be attributed to the weak capital market that exists in the country. As explained by Lall (1973) that Africa lacks the capital (which Ghana is not an exception). For large investment, this therefore suggests that foreign investors do not concentrate on domestic capital market but rather search for funds in the world capital market. This may be the reason why the domestic interest rate does not have any significant effect in attracting foreign direct investment into the country.

The regression also shows that in the short-run, volatility of interest rate has a significant effect on volatility of exchange rate. The short-term effect of interest rate on exchange rate may be as a result of interest rate affecting other trade determinants which in turn affect exchange rate. The paper therefore confirms the findings of Campa (1993) and Koldstad (1995) study that a stable exchange rate through the influence of effective macroeconomic policies that improves the domestic interest rate enhances FDI inflows into the domestic environment. On the contrary, it does not however support Blonigen (1997), and Froot and Stein (1991) paper that depreciation of the US dollar relative to the Yen increases inward US acquisition FDI by Japanese firms. Whereas results of this studies suggest that a stable exchange rate regime influence an increase in FDI inflows, most of the studies conducted in the developed world shows that depreciation of the domestic currency rather enhances FDI inflow into the domestic economy. The difference in the estimation results of the paper from that of Froot and Stein (1991) and Klein and Rosengren (1994) may be due to several factors. The first is, the U.S economy has sufficient capital and management expertise available for the foreign investor, such capital and expertise are lacking in Ghana. Due to lack of such a expertise in the country, the foreign investor needs to import such inputs and in situations where the domestic currency is depreciating, cost of production of the foreign investor will also increase making the foreign investor to wait for a stable economic environment. Another important contributing factor causing the difference is also imperfect capital market assumption suggested by Froot and Stein. Although capital may not be perfectly mobile, there is some extent of easily mobility in the past years.

In order to improve the exchange rate stability, the government should implement policies which would reduce importation but rather increase exportation of the country. One way for the country to reduce importation is to increase production of agric commodities that can be supported by the national climate so as to reduce the importation of such commodities. In order to increase exportation, farmers in exporting commodities like cocoa, pineapples, etc., should be thought on how to use a high yield seeds and better farming practices to increase the yield of such commodities. Another way to stabilize the exchange rate is for the government to cut down its' budget expenses to reduce external borrowing. In doing so, the exchange rate can be stabilize thereby improving FDI inflows into the country.

Moreso, effective monetary policies should be conducted by the government to improve the Cedi-Dollar exchange rates. Policies that will reduce inflation so as to reduce importation should be implemented, this is because domestic goods becomes expensive than importation of foreign substitute goods will increase there by destabilizing the exchange rate. Example, because of the high prices in the country, Ghanaians prefer buying cheap textiles imported from china. To prevent this, the government should try to implement policies that will reduce cost of production by local firms and also educate Ghanaians firms to make their products able to compete with the outside world.

Since, the Ghanaian economy have comparative advantage in the production of rice, favourable environment should be provided by the government to Ghanaians to produce rice in order to reduce the quantity of rice imported into the country as rice importation forms a substantial amount in the commodities that the nations import. Finally, to improve stability of the Cedi, the government should invest in research into other ways to provide fuel locally (e.g. production of biodiesel). This is because if the country is able to reduce fuel importation, then this will reduce the value of importations into the Ghanaian economy. When all these measurement are effectively implemented by the government of Ghana, importation will be reduce and exportation will increase and this will improve the country's trade stance thereby reducing the high rate of depreciation of the Cedi.

In summary, one can therefore conclude from this study that the stabilization of the country's currency over the last five years is a step in the right direction to improve the inflow of FDI. Since the empirical evidence suggests that if the country is able to reduce the volatility of exchange rate and interest rate in the near future, FDI inflows will also be increase and as Frimpong (2005) and other researchers have found a positive correlation between FDI in Ghana and economic growth. The aim of policy makers to achieve a middle income status by the year 2020 may be a reality if the effect of exchange rate and interest rate in attracting FDI inflows are considered by monetary policy makers in their policy debates.

Future studies should explore the possibility of using sector or industry specific data in order to establish robust results. Moreso, future research should try to treat exchange rate as endogenous variable in estimating FDI determinant model. Future research should also consider the use of country specific data of FDI, so as to make application of panel data analysis possible in order to attain more robust results since FDI inflows into the country in recent years by the East Asian countries are on the increase. 


\section{References}

[1] Arbenser, Lawrence (2007). A General Equilibrium Analysis of the Impact of Inward FDI on Ghana. http:/www.isser.org/FDI\%20on\%20Ghana

[2] Blonigen, Bruce A. (1997). Firm-Specific Assets and the Link Between Exchange Rates and Foreign Direct Investments. American economic review; 87(3); page: 447465

[3] Campa, Joes M. (1993). "Entry by Foreign Firms in the United State under exchange rate uncertainity", Review of economics and statistics, 75,614-622

[4] Carkovic, M. and R. Levine (2005). Does Foreign Direct Investment Accelerates Economic Growth. Institute of International Economics, Washington DC page: 195-220

[5] Contractor, F.(1991). Do government Policies towards foreign direct policies matter? An empirical investigation of the link between national policies and FDI flows. UNCTC current series A(21), United Nations, New York.

[6] Dunning John H. (994). Re-evaluating the benefits of foreign direct investment. Transactional corporations, vol. 3,no. 1: page 23-51

[7] Dunning, John H. (1980). Toward an eclectic theory of international production: some empirical tests. Journal of international business studies, vol. 11, no.1; page: 9-31

[8] Froot, Kenneth A. and Jeremy C. Stein (1991). Exchange Rates and Foreign Direct Investment: An imperfect Capital Markets Approach. http://www.jstor.org/stable/29737961

[9] Goldberg, Linda S. and Charles Koldstad D. (1995). Foreign Direct Investment exchange rate variability and demand uncertainty. International economic review, 36,855-873

[10] Government of Ghana Publication, 2002. Ghana Investment Promotion council annual Report 2002

[11] Government of Ghana Publication, 2006. Ghana Investment Promotion council Quarterly Report 2006

[12] Grubert Harry and John Mutti, (1991). Taxes, Tarrifs and Transfer Pricing in Multinational Corporation Decision Making. Review of economics and statistics, 74(2): pp. 285293
[13] Hansen H. and J. Rand (2006). The Causal Links Between FDI and Growth in Developing Countries. The World Economy. 29(1), page:21-41

[14] Harrison, Ann (1996). Determinants and Effects of Foreign Direct Investment in Cote d'Ivoire, Morocco and Venezuela. New York: oxford University Press for the World Bank, page: 163-186

[15] Johansen, S. (1988). Statistical analysis of co-integration vectors. Journal of Economic Dynamics and Control 110; Page: 495-525

[16] Klein, Mathew W., Joe Peek, and Eric S. Rosengren (1996). Troubled Bank, Impaired Foreign Direct Investment: The Role of Relative Access To Credit. The American Economic Review 92(3),pp. 664-682.

[17] Kogut, Bruce and Sea, Jin Chang (1996). Platform investment and volatile exchange rate: Direct investment in the US by Japanese Electronic companies. Review of economics and statistics 78(2): pp 221-231

[18] Lall, Sanjaya (1973). Transfer Pricing by multinational manufacturing firms. Oxford Bulletin of Economics and Statistics. 35: pp 173-95

[19] Magnus, Frimpong Joseph and Eric Fosu Oteng-Abeyie (2006). Bivariate analysis between FDI inflows and economic growth in Ghana. http://mpra.ub.unimuenchen.de/351/

[20] Osterward-Lenum, Michael (1992). A Note with Quantiles of the Asymptotic Distribution of the Maximum Likelihood Co-integration Rank test Statistics. Oxford Bulletin of Economics and Statistics, Vol. 54 (August), page 461-71

[21] Sim, CA(1980). Macroeconomic and reality. Econometrica 48; page: $1-48$

[22] Steel, William F (1988). Recent Policy Reform and Industrial Adjustment in Zambia and Ghana. The Journal of Modern African Studies. Vol. 26, page: 157-164

[23] Swenson, Deborah L(2004). Foreign investment and mediation of trade flows. Review of international economics, 12(4); Page: $609=629$

[24] UNCTAD (2005). Economic development of Africa: Rethinking the Role of Foreign Direct Investment. UNCTAD/GDS/AFRICA/2005/1, United Nations, Geneva 